\title{
Salicylic acid modulates arsenic toxicity by reducing its root to shoot translocation in rice (Oryza sativa L.)
}

\author{
Amit P. Singh, Garima Dixit, Seema Mishra, Sanjay Dwivedi, Manish Tiwari, \\ Shekhar Mallick, Vivek Pandey, Prabodh K. Trivedi, Debasis Chakrabarty and \\ Rudra D. Tripathi *
}

Division of Plant Ecology and Environmental Science, Department of Environmental Science, Council of Scientific and Industrial Research - National Botanical Research Institute, Lucknow, India

\section{OPEN ACCESS}

Edited by:

Girdhar Kumar Pandey,

University of Delhi, India

Reviewed by:

Sudhakar Srivastava,

Bhabha Atomic Research Centre,

India

Ashish Kumar Srivastava, Bhabha Atomic Research Centre,

India

${ }^{*}$ Correspondence:

Rudra D. Tripathi,

Division of Plant Ecology and Environmental Science,

Department of Environmental

Science, Council of Scientific and Industrial Research - National

Botanical Research Institute, KN Kaul Block, Lucknow, 226001 UP, India

tripathird@gmail.com;

tripathi_rd@rediffmail.com

Specialty section:

This article was submitted to Plant Physiology,

a section of the journal Frontiers in Plant Science

Received: 04 February 2015 Accepted: 29 April 2015 Published: 18 May 2015

Citation:

Singh AP, Dixit G, Mishra S,

Dwivedi S, Tiwari M, Mallick S, Pandey V, Trivedi $P K$, Chakrabarty D and Tripathi RD (2015) Salicylic acid

modulates arsenic toxicity by reducing its root to shoot translocation in rice (Oryza sativa L.).

Front. Plant Sci. 6:340. doi: 10.3389/fp/s.2015.00340
Arsenic (As) is posing serious health concerns in South East Asia where rice, an efficient accumulator of As, is prominent crop. Salicylic acid (SA) is an important signaling molecule and plays a crucial role in resistance against biotic and abiotic stress in plants. In present study, ameliorative effect of SA against arsenate $(A s \mathrm{~V})$ toxicity has been investigated in rice (Oryza sativa L.). Arsenate stress hampered the plant growth in terms of root, shoots length, and biomass as well as it enhanced the level of $\mathrm{H}_{2} \mathrm{O}_{2}$ and MDA in dose dependent manner in shoot. Exogenous application of SA, reverted the growth, and oxidative stress caused by $\mathrm{As}^{\mathrm{V}}$ and significantly decreased $\mathrm{As}$ translocation to the shoots. Level of As in shoot was positively correlated with the expression of OsLsi2, efflux transporter responsible for root to shoot translocation of As in the form of arsenite $\left(A s^{\text {III }}\right)$. SA also overcame $A s^{V}$ induced oxidative stress and modulated the activities of antioxidant enzymes in a differential manner in shoots. As treatment hampered the translocation of $\mathrm{Fe}$ in the shoot which was compensated by the SA treatment. The level of $\mathrm{Fe}$ in root and shoot was positively correlated with the transcript level of transporters responsible for the accumulation of Fe, OSNRAMP5, and OSFRDL1, in the root and shoot, respectively. Co-application of SA was more effective than pre-treatment for reducing As accumulation as well as imposed toxicity.

Keywords: arsenate, salicylic acid, rice seedlings, antioxidants, Fe transporters

\section{Introduction}

Arsenic (As) is posing a serious health concern in South East Asia especially in Bangladesh and West Bengal in India. Long term As exposure leads to skin lesions and various types of cancers (Kumar et al., 2015). Safe level of As in drinking water is $10 \mu \mathrm{g} \mathrm{l^{-1 }}$, as recommended by World Health Organization in 1993, while the level of As in ground water has been reported up to $3200 \mathrm{\mu g} \mathrm{l}^{-1}$ in West Bengal and Bangladesh that is enough to show the severity of problem (McCarty et al., 2011). Arable land can be contaminated through irrigation by As rich water. More than $90 \%$ production of rice comes from South East Asia that is heavily contaminated by As, thus significant amount of As also accumulates in various parts of rice which serves as a major entry route for As in to food chain. Presence of As in grains also hampers the nutritional value of rice in terms of trace nutrients and amino acids (Kumar et al., 2014a). 
Arsenic is non-essential element for plant and present in environment both in inorganic as well as organic forms. Arsenate $\left(A s^{\mathrm{V}}\right)$ and arsenite $\left(\mathrm{As}{ }^{\mathrm{III}}\right)$ are predominant inorganic forms. As toxicity symptoms in plants range from inhibition of root growth, photosynthesis to death of plant (Mishra et al., 2014; Kumar et al., 2015). Arsenate shows structural analogy with phosphate so it is mainly transported through high affinity phosphate transporters (Tripathi et al., 2007). In paddy field, As ${ }^{\text {III }}$ is the predominant chemical species of As due to anaerobic growing conditions (Takahashi et al., 2004). Further, most of the As taken up by the plants is also reduced and stored as As ${ }^{\mathrm{III}}$ (Pickering et al., 2000; Mishra et al., 2013). Arsenite is transported through aquaporin channels. Two major As ${ }^{\mathrm{II}}$ transporters, Lsi1 and Lsi2 have been reported in rice. Lsil is localized at the distal side of both exodermis and endodermis cells of rice roots and mediates the influx of As ${ }^{\mathrm{III}}$. Lsi2 is localized at the proximal side of both exodermis and endodermis cells and plays an important role in As ${ }^{\mathrm{III}}$ transport to the shoots and ultimately to the rice grains (Ma et al., 2008). Arsenate can replace phosphate from many biochemical reactions leading to disruption of energy flow while $A s^{\mathrm{III}}$ interferes with functioning of proteins and enzymes through thiol interaction (Finnegan and Chen, 2012). As is a redox active metalloid and induces the generation of reactive oxygen species (ROS) leading to lipid peroxidation, disruption of cellular redox state, and associated toxicity (Finnegan and Chen, 2012). In rice As mediated redox imbalance has been shown to the major factor causing toxicity (Srivastava et al., 2014). To cope up with ROS production plants are equipped with various antioxidant enzymes and molecules (GSH, Ascorbate). GSH also serves as substrate for phytochelatins (PCs), the metal and metalloids chelating ligands, therefore, reduces free As inside cell (Kumar et al., 2014b).

Salicylic acid and its derivative (acetylsalicylic acid) have been used for therapeutic purpose since more than a century. SA is synthesized by two pathways, the isochorismate pathway and the phenylalanine ammonia-lyase pathway (Vlot et al., 2009). $\mathrm{SA}$ is an important signaling molecule and its role in protection against various biotic and abiotic stresses has been well studied in plants (Yuan and Lin, 2008; Vlot et al., 2009). Upon pathogen attack endogenous level of SA gets enhanced and binds to catalase (CAT) that leads to enhanced level of $\mathrm{H}_{2} \mathrm{O}_{2}$. The $\mathrm{H}_{2} \mathrm{O}_{2}$ serves as secondary messenger to induce the expression of pathogen related proteins and ultimately initiates systemic acquired resistance (Vlot et al., 2009). SA has been reported to provide protection against heavy metal stress such as, against mercury in Medicago sativa (Zhou et al., 2009), cadmium stress in barley, rice and soybean (Metwally et al., 2003; Guo et al., 2007; Noriega et al., 2012), and against nickel stress in mustard (Yusuf et al., 2012). Guo et al., (2007) hypothesized that enhanced level of $\mathrm{H}_{2} \mathrm{O}_{2}$ by SA serves as secondary messenger to improve plant defense against abiotic stress. SA is reported to abate the chlorosis under iron deficient conditions and also promotes iron $(\mathrm{Fe})$ uptake and translocation in Arachis hypogaea (Kong et al., 2014) and enhanced mineral nutrient uptake including $\mathrm{Fe}$ in maize (Gunes et al., 2007).

Iron acquisition mechanism in various plants is divided in two main categories: Strategy I in non-graminaceous plants and
Strategy II in graminaceous plants (Römheld and Marschner, 1986). The two main processes in the Strategy I are the reduction of ferric chelates $\left(\mathrm{Fe}^{+3}\right.$-chelate) at the root surface and the absorption of the generated ferrous $\left(\mathrm{Fe}^{+2}\right)$ ions across the root plasma membrane (Kobayashi and Nishizawa, 2012). Rice belongs to family graminae which uses strategy II for Fe uptake where the plant roots secretes mugenic acid (MA) that forms $\mathrm{Fe}^{+3}$-MA complex and is taken up by root cells by YSL transporters (Kobayashi and Nishizawa, 2012). There are several Fe transporters in which OsFRDL1, OsYSL2, and OsNRAMP5 follow strategy II and uptake only chelated $\mathrm{Fe}^{+3}$, but rice also has a unique transporter OsIRT1 which enables the plant to directly uptake the $\mathrm{Fe}^{+2}$ from soil beyond the strategy II (Ishimaru et al., 2006). The key regulator of Fe transporters is OsIRO2, strongly induced under iron deficient conditions (Ogo et al., 2007). OsFRDL1 is expressed in rice root pericycle and encodes citrate effluxer that is required for efficient $\mathrm{Fe}$ translocation (Yokosho et al., 2009) and OsYSL2 is responsible for long distance transport of chelated $\mathrm{Fe}^{+3}$ to sink tissues (Ishimaru et al., 2010). Along with the $\mathrm{Fe}^{+3}$, OsNRAMP5 also contributes to $\mathrm{Mn}^{+2}$ and $\mathrm{Cd}^{+2}$ transport in rice (Ishimaru et al., 2012).

This study is hypothesized to investigate positive impact of SA on $\mathrm{As}^{\mathrm{V}}$ tolerance in rice. We analyzed changes in As accumulation, oxidative stress, antioxidant enzymes activities, $\mathrm{As}^{\mathrm{III}}$, and $\mathrm{Fe}$ transporters in $\mathrm{As}^{\mathrm{V}}$ exposed plants under co-application, and pre-treatment of SA.

\section{Materials and Methods}

\section{Growth Conditions and Experimental Design}

Seeds of Oryza sativa cv. Pant4 collected from Masina Research Centre, Pvt. Ltd., Bihar (India), were surface sterilized using 10\% $\mathrm{H}_{2} \mathrm{O}_{2}$ for $30 \mathrm{~s}$ and washed with Milli Q water. Seeds were germinated on moist pre-sterilized blotting sheets in a tray, placed in seed germinator for 4 days at $25^{\circ} \mathrm{C}$, relative humidity was $65 \%$. After 7 days, 50 uniform size seedlings were selected and placed in $150 \mathrm{ml}$ beakers, covered with black sheet, containing $100 \mathrm{ml}$ of $100 \%$ Hewitt nutrient medium, prepared in Milli-Q water $(\mathrm{pH}$ 6.8-7.0) and grown for another 10 days under light intensity $210 \mu \mathrm{M} \mathrm{cm}^{-2} \mathrm{~s}^{-1}$ (16/8 h; day/night). 10 days old plants were provided $\mathrm{As}^{\mathrm{V}}(25$ and $50 \mu \mathrm{M})$ using the salt $\mathrm{Na}_{2} \mathrm{HAsO}_{4}$ and $\mathrm{SA}$ $(100 \mu \mathrm{M})$ in the nutrient medium and grown for 7 days. Plants treated by 25 and $50 \mu \mathrm{M} \mathrm{As}{ }^{\mathrm{V}}, 100 \mu \mathrm{M}$ SA for 7 days abbreviated as $A s{ }^{\mathrm{V}} 25, A s \mathrm{~V}^{2} 0$ and $\mathrm{SA}$, respectively. Plants treated with $\mathrm{As}^{\mathrm{V}} \mathrm{V}_{25}$, $A s^{\mathrm{V}} 50$ supplemented with $\mathrm{SA}$ abbreviated as $\mathrm{SA}+\mathrm{As}^{\mathrm{V}} 25$ and $\mathrm{SA}+\mathrm{As}^{\mathrm{V}} 50$. For Pre-treatment of SA, plants were grown in $100 \mu \mathrm{M}$ SA for 3 days and then transferred to Hewitt solution containing $\mathrm{As}^{\mathrm{V}} 25, \mathrm{As}^{\mathrm{V}} 50$ for 7 days and they are abbreviated as $\mathrm{SA}$ Pre $+\mathrm{As}^{\mathrm{V}} 25$ and $\mathrm{SA}$ Pre $+\mathrm{As}^{\mathrm{V}} 50$. Plants grown in $\mathrm{As}^{\mathrm{V}}$ deprived medium termed as SA Pre and plants grown only in Hewitt solution served as control.

\section{Estimation of Chlorophyll and Carotenoids}

Fresh leaves $(0.1 \mathrm{~g})$ were crushed in $5 \mathrm{ml}$ of $80 \%$ acetone and centrifuged at $10,000 \times g$ for $10 \mathrm{~min}$. The supernatant was 
used for estimation of chlorophyll by Arnon (1949) method and carotenoids by Duxbury and Yentsch (1956) method.

\section{Estimation Hydrogen Peroxide and MDA}

Fresh leaves $(0.5 \mathrm{~g})$ were crushed in $5 \mathrm{ml}$ of $0.1 \%$ trichloroacetic acid and centrifuged at $10,000 \times g$ for $10 \mathrm{~min}$. The supernatant was used for estimation of MDA and $\mathrm{H}_{2} \mathrm{O}_{2}$. MDA and $\mathrm{H}_{2} \mathrm{O}_{2}$ by Heath and Packer (1968) and Velikova et al. (2000), respectively.

\section{Assay of Antioxidant Enzymes}

Fresh leaves $(0.3 \mathrm{~g})$ were ground in liquid $\mathrm{N}_{2}$ using a mortar, and homogenized in $3 \mathrm{ml}$ of buffer containing $50 \mathrm{mM}$ potassium phosphate buffer ( $\mathrm{pH} 7.8)$ and $1 \%(\mathrm{w} / \mathrm{v})$ polyvinylpyrrolidone. The homogenate was centrifuged at $8000 \times g$ at $4^{\circ} \mathrm{C}$ for $15 \mathrm{~min}$. and supernatant was used for ascorbate peroxidase (APX), guaiacol peroxidase (GPX), CAT, superoxide dismutase (SOD), and Nitrate reductase (NR) activity, and nitrite and soluble protein concentration.

The activity of SOD (EC 1.15.1.1) was measured by Beauchamp and Fridovich (1971), APX (EC 1.11.1.11) by Nakano and Asada (1981), GPX (EC 1.11.1.7) by Kato and Shimizu (1987), CAT (EC 1.11.1.6) by Scandalios et al. (1983), NR (EC 1.7.99.4), and nitrite by Hageman and Reed (1980).

\section{Estimation of Non-Protein Thiolic Metabolites and Ascorbic Acid}

The level of GSH and GSSG was measured by following the protocol of Hissin and Hilf (1976). Plant material (500 mg) was frozen in liquid nitrogen and homogenized in $0.1 \mathrm{M}$ sodium phosphate buffer $(\mathrm{pH} 8.0)$ containing $25 \%$ meta-phosphoric acid. The homogenate was centrifuged at $20,000 \times g$ for $20 \mathrm{~min}$ at $4^{\circ} \mathrm{C}$. Total glutathione (GSSG and GSH) content was determined fluorometrically in the supernatant after $15 \mathrm{~min}$ incubation with $o$-phthaldialdehyde (OPT). Fluorescence intensity was recorded at $420 \mathrm{~nm}$ after excitation at $350 \mathrm{~nm}$ on a Hitachi F 7000 fluorescence spectrophotometer.

Non-protein thiol (NPT) content was measured by following the method of Ellman (1959). The concentration of PCs was calculated as PCs $=\mathrm{NPT}-(\mathrm{GSH}+\mathrm{GSSG}$; Duan et al., 2011).

For estimation of ascorbic acid (Asc), fresh leaves $(0.5 \mathrm{~g})$ were crushed in $5 \mathrm{ml}$ of $0.1 \%$ trichloroacetic acid and homogenate was centrifuged at $10,000 \times g$ for $10 \mathrm{~min}$. The supernatant was used for estimation of Asc by Shukla et al. (1979).

\section{Element Estimation}

The elements (As and $\mathrm{Fe}$ ) content was determined following Mallick et al. (2012). Briefly, plant tissues were washed three times with Milli Q water and plants separated in root and shoot and oven dried at $70^{\circ} \mathrm{C}$. Dried plant tissues (root 300 and shoot $500 \mathrm{mg}$ ) were digested in $\mathrm{HNO}_{3}: \mathrm{HCl}$ (3:1). Digested samples were filtered through Whatman filter paper 42 and volume was made to $10 \mathrm{ml}$ by Milli-Q water. As and Fe were estimated by using AAS (GBC Avanta S, USA) fitted with a hydride generator (MDS 2000) using $\mathrm{NaH}_{2} \mathrm{BO}_{4}+\mathrm{NaOH}(3 \mathrm{M})$ and $\mathrm{HCl}(3 \mathrm{M})$. The values were presented in $\mu \mathrm{g}$ per gram dry weight $\left(\mu \mathrm{g} \mathrm{g}^{-1} \mathrm{dw}\right)$.

\section{Endogenous Salicylic Acid Estimation}

Presence of SA in shoot samples were analyzed by HPLC (Dionex Ultimate 3000) using UV detector at $210 \mathrm{~nm}$ by following the method of Pan et al. (2010). The mobile phase was programmed with linear gradient of A ( $0.1 \%$ of formic acid in methanol) and B ( $0.1 \%$ of formic acid in water) as $0-20 \mathrm{~min} ; 30-100 \% \mathrm{~A}, 20-$ $22 \mathrm{~min} ; 100 \% \mathrm{~A}$ and then $22-25 \mathrm{~min} ; 100-30 \%$ of A. Flow rate was maintained at $0.3 \mathrm{ml} \mathrm{min}^{-1}$. Retention time for SA was recorded at $22.4 \mathrm{~min}$.

\section{Gene Expression Analysis Using Quantitative RT-PCR}

Approximately $5 \mu \mathrm{g}$, RNase free DNase-treated, total RNA isolated from roots of rice plants was reverse-transcribed using SuperScriptII (Fermentas, USA), following the manufacturer's recommendation. The synthesized cDNA was diluted 1:5 in DEPC water and subjected to quantitative RT-PCR (qRT-PCR) analysis. The qRT-PCR was performed using an ABI 7500 instrument (ABI Biosystems, USA) using primers listed in Supplementary Table S1. Each qPCR reaction contained $5 \mu$ l of SYBR Green Supermix (ABI Biosystems, USA), $1 \mu \mathrm{l}$ of the diluted cDNA reaction mixture (corresponding to $5 \mathrm{ng}$ of starting amount of RNA) and $10 \mathrm{pM}$ of each primer in a total reaction volume of $10 \mu \mathrm{l}$. The $\mathrm{qPCR}$ reactions were performed under following conditions: $10 \mathrm{~min}$ at $95^{\circ} \mathrm{C}$ and 40 cycles of the one step thermal cycling of $3 \mathrm{~s}$ at $95^{\circ} \mathrm{C}$ and $30 \mathrm{~s}$ at $60^{\circ} \mathrm{C}$ in a 96-well reaction plate. Actin gene was used as an internal control to estimate the relative transcript levels of the target gene. Specificity of amplicons generated in qPCR reactions was verified by melt curve analysis. Each qPCR reaction was performed in triplicate (technical replicates) for each biological replicate (three for each treatment). Relative gene expression was calculated using ${ }^{\Delta \Delta} \mathrm{CT}$ method (Livak and Schmittgen, 2001).

\section{Statistical Analysis and Analytical Quality Control}

The whole experiment was set up in the randomized block design. The data were subjected to Duncan's Multiple Range Test (DMRT) for the analysis of significant difference between the treatments. Analytical data quality of the elements, was ensured through repeated analysis $(n=6)$ of Standard Reference Material. Standard Certified reference material (CRM 028-050) used for the accuracy of the AAS procured from Resource Technology Corporation, USA (Lot no. IH 028), and the values obtained varied between -3.97 to $22.86 \%$ error between ten measurements. The blanks were run all the time to eliminate the background noise.

\section{Results}

\section{Morphology and Photosynthetic Pigments}

Arsenate had deleterious impact on plant growth. A dose dependent decrease of 6 and $17 \%$ at $25 \mu \mathrm{M}$ and 26 and $31 \%$ at $50 \mu \mathrm{M}$ $\mathrm{As}^{\mathrm{V}}$ was observed in root and shoot, respectively, than control. SA alone treatment enhanced the root and shoot length by 39 
and 19\%, respectively, than control. Co-application of SA and $\mathrm{As}^{\mathrm{V}} 50$ enhanced the root and shoot growth significantly (58 and $36 \%$, respectively) than $50 \mu \mathrm{M} \mathrm{As}{ }^{\mathrm{V}}$ alone treated plants. SA pretreated plants also experienced less toxicity during exposure to $\mathrm{As}^{\mathrm{V}}$. Arsenate induced reduction in biomass was also significantly recovered by SA supplementation. Under As ${ }^{\mathrm{V}}$ stress total chlorophyll was reduced significantly in dose dependent manner with maximum approximately $22 \%$ reduction at $50 \mu \mathrm{M} \mathrm{As} V$ than control while carotenoid content was increased significantly in $\mathrm{As}^{\mathrm{V}} 50$ treatment than control. SA co-application with $\mathrm{As} \mathrm{V}^{\text {, }}$ reverted chlorophyll loss caused by $\mathrm{As}^{\mathrm{V}}$ stress (Table 1).

\section{Element Content in Root and Shoot}

The rice plants accumulated significant amount of As in upon exposure to $\mathrm{As}^{\mathrm{V}}$ in dose dependant manner. In all treatments more than $90 \%$ of As was confined in to the roots. SA coapplication to $\mathrm{As}^{\mathrm{V}}$ treated plants had no significant impact on As accumulation in root. However, the shoot As was reduced significantly, i.e., around $30 \%$ reduction in both $\mathrm{SA}+\mathrm{As}^{\mathrm{V}} 25$ and $\mathrm{SA}+\mathrm{As}^{\mathrm{V}} 50$ than $\mathrm{As}{ }^{\mathrm{V}}$ alone treated plants was observed. SA pretreated plants also accumulated 16 and $17 \%$ less As in shoot upon exposure to 25 and $50 \mu \mathrm{M} \mathrm{As}{ }^{\mathrm{V}}$, respectively, (Table 2).

Arsenate treatment significantly enhanced total Fe accumulation in comparison to control plants. However, the most of the accumulated $\mathrm{Fe}$ was localized in the roots. The translocation of Fe to shoot was reduced drastically (6\% of total accumulation at
$\mathrm{As}^{\mathrm{V}} 50$ ) in $\mathrm{As} \mathrm{V}$ treated plants which was $33 \%$ lower than control shoot. Co-application as well as pre-treatment of SA reduced the total $\mathrm{Fe}$ accumulation in comparison to $\mathrm{As} \mathrm{V}$ alone, however, its translocation to shoots increased significantly, i.e., 30 and $45 \%$ increased at $\mathrm{SA}+\mathrm{As}^{\mathrm{V}} 25$ and $\mathrm{SA}+\mathrm{As}^{\mathrm{V}} 50$ than $\mathrm{As}^{\mathrm{V}}$ alone treated shoots and the level of Fe in shoots were comparable to control (Table 2).

\section{Oxidative Stress and Antioxidants}

Salicylic acid alone treatment had no significant impact on MDA content in rice shoot while $\mathrm{H}_{2} \mathrm{O}_{2}$ content was enhanced by $28 \%$ than control. Arsenate treatment enhanced the MDA content by ca. three- and fourfolds at 25 and $50 \mu \mathrm{M}$ As ${ }^{\mathrm{V}}$ exposed plants, respectively, than control. Similar trend was observed in $\mathrm{H}_{2} \mathrm{O}_{2}$ content. Pre-treatments as well as co-application of SA and $\mathrm{As}^{\mathrm{V}}$ has reduced the level of MDA and $\mathrm{H}_{2} \mathrm{O}_{2}$ than $\mathrm{As}^{\mathrm{V}}$ alone treated plants, although co-application was more effective than pre-treatment (Figures 1A,B).

Salicylic acid treatment also moderated $\mathrm{As}^{\mathrm{V}}$ induced antioxidant activities. SOD activity got enhanced ca. two- and threefolds, respectively, in $\mathrm{As}^{\mathrm{V}} 25$ and $\mathrm{As}^{\mathrm{V}} 50$ treated plants in shoot than control. Co-application of $\mathrm{SA}$ and $\mathrm{As}{ }^{\mathrm{V}}$ significantly reduced $\mathrm{SOD}$ activity which was about 42 and $55 \%$ than $\mathrm{As}^{\mathrm{V}} 25$ and $\mathrm{As}^{\mathrm{V}} 50$, respectively. SA pre-treatment to $\mathrm{As}^{\mathrm{V}}$ exposed plants showed 32 and $50 \%$ less SOD activity the respective $\mathrm{As}^{\mathrm{V}}$ treatments (Figure 1C).

TABLE 1 | Effect on shoot, root lengths (cm), fresh-weight $(\mathrm{mg})$, total chlorophyll (mg $\left.\mathrm{g}^{-1} \mathrm{fw}\right)$, and carotenoid content (mg $\left.\mathrm{g}^{-1} \mathrm{fw}\right)$ Oryza sativa after 7 days of treatment with different combinations of Arsenate (As ${ }^{\mathrm{V}}$ ) and Salicylic acid (SA).

\begin{tabular}{|c|c|c|c|c|c|}
\hline & Root length & Shoot length & Biomass & Total chl & Carotenoids \\
\hline Control & $3.88^{\mathrm{cd}} \pm 0.26$ & $26.3^{\text {de }} \pm 1.8$ & $274.24^{d} \pm 0.01$ & 2.29 de \pm 0.06 & $0.15^{a b} \pm 0.008$ \\
\hline SA & $5.40^{9} \pm 0.36$ & $31.3^{f} \pm 2.5$ & $345.51^{f} \pm 0.0$ & $2.44^{f} \pm 0.08$ & $0.15^{b c} \pm 0.008$ \\
\hline $\mathrm{As}^{\mathrm{V}_{25}}$ & $3.63^{b c} \pm 0.29$ & $21.8^{\mathrm{bc}} \pm 1.4$ & $226.84^{a b} \pm 0.07$ & $1.94^{b} \pm 0.02$ & $0.18^{e f} \pm 0.004$ \\
\hline $\mathrm{As}^{\mathrm{V}_{50}}$ & $2.85^{a} \pm 0.19$ & $18.0^{\mathrm{a}} \pm 1.2$ & $218.94^{a} \pm 0.07$ & $1.79^{a} \pm 0.07$ & $0.18^{f} \pm 0.006$ \\
\hline$S A+A s^{V} 25$ & $4.88^{f} \pm 0.33$ & $26.3^{\text {de }} \pm 1.7$ & $266.79^{\mathrm{cd}} \pm 0.06$ & $2.31^{e} \pm 0.01$ & $0.14^{\mathrm{a}} \pm 0.004$ \\
\hline$S A+A s^{V} 50$ & $4.50 e^{f} \pm 0.30$ & $24.5^{\mathrm{cd}} \pm 1.9$ & $248.73^{b c d} \pm 0.01$ & $2.17^{c} \pm 0.02$ & $0.16^{\mathrm{cd}} \pm 0.001$ \\
\hline SA Pre & $4.28^{\text {de }} \pm 0.29$ & $28.1^{\mathrm{e}} \pm 1.9$ & $312.84^{e} \pm 0.016$ & $2.48^{f} \pm 0.05$ & $0.16^{\mathrm{cd}} \pm 0.001$ \\
\hline SA Pre $+A s^{V_{2}} 25$ & $3.52^{b c} \pm 0.28$ & $24.3^{\mathrm{cd}} \pm 1.6$ & $253.36^{\text {bcd }} \pm 0.08$ & $2.22^{\text {cde }} \pm 0.05$ & $0.17^{\text {de }} \pm 0.007$ \\
\hline SA Pre + As $^{V_{50}}$ & $3.33^{a b} \pm 0.26$ & $20.6^{\mathrm{ab}} \pm 1.4$ & $239.91^{\mathrm{abc}} \pm 0.01$ & $2.19^{\mathrm{cd}} \pm 0.05$ & $0.17^{\text {de }} \pm 0.008$ \\
\hline
\end{tabular}

Values marked with same alphabets are not significantly different (DMRT, $p<0.05)$. All the values are means of three replicates $\pm S D$.

TABLE 2 | Accumulation ( $\mu \mathrm{g} \mathrm{g}^{-1} \mathrm{dw}$ ) of Arsenic (As) and Fe in the root and shoot of Oryza sativa after 7 days of treatment with different combinations of As $\mathrm{V}$ and SA.

\begin{tabular}{|c|c|c|c|c|}
\hline & As root & As shoot & Fe root & Fe shoot \\
\hline Control & - & - & $364.2^{\mathrm{a}} \pm 18.1$ & $60.2^{\text {cde }} \pm 5.1$ \\
\hline SA & - & - & $403.3^{a} \pm 30.0$ & $68.3^{e} \pm 7.1$ \\
\hline$A s V_{25}$ & $317.82^{a} \pm 66.2$ & $28.84^{b c} \pm 2.7$ & $566.6^{\mathrm{bc}} \pm 49.2$ & $48.4^{a b} \pm 5.8$ \\
\hline$A s^{V_{50}}$ & $454.26^{b} \pm 22.2$ & $38.00^{d} \pm 4.1$ & $632.5^{c} \pm 61.3$ & $40.2^{a} \pm 3.3$ \\
\hline$S A+A s^{V} 25$ & $290.83^{a} \pm 42.9$ & $19.96^{a} \pm 2.3$ & $522.4^{b} \pm 63.1$ & $62.8^{\text {de }} \pm 3.9$ \\
\hline$S A+A s^{V_{50}}$ & $426.74^{b} \pm 56.9$ & $26.55^{b c} \pm 2.9$ & $528.8^{b} \pm 41.1$ & $58.3^{\text {cde }} \pm 4.4$ \\
\hline SA Pre & - & - & $409.2^{\mathrm{a}} \pm 17.7$ & $64.4^{\text {de }} \pm 4.6$ \\
\hline SA Pre $+\mathrm{As}^{\mathrm{V}_{25}}$ & $302.56^{a} \pm 46.9$ & $24.22^{\mathrm{ab}} \pm 2.7$ & $486.6^{b} \pm 38.4$ & $55.8^{\mathrm{bcd}} \pm 5.8$ \\
\hline SA Pre + As $^{V_{50}}$ & $432.32^{b} \pm 53.3$ & $31.19^{c} \pm 1.8$ & $551.4^{b} \pm 43.6$ & $52.3^{b c} \pm 6.6$ \\
\hline
\end{tabular}

Values marked with same alphabets are not significantly different (DMRT, $p<0.05)$. All the values are means of four replicates $\pm S D$. 


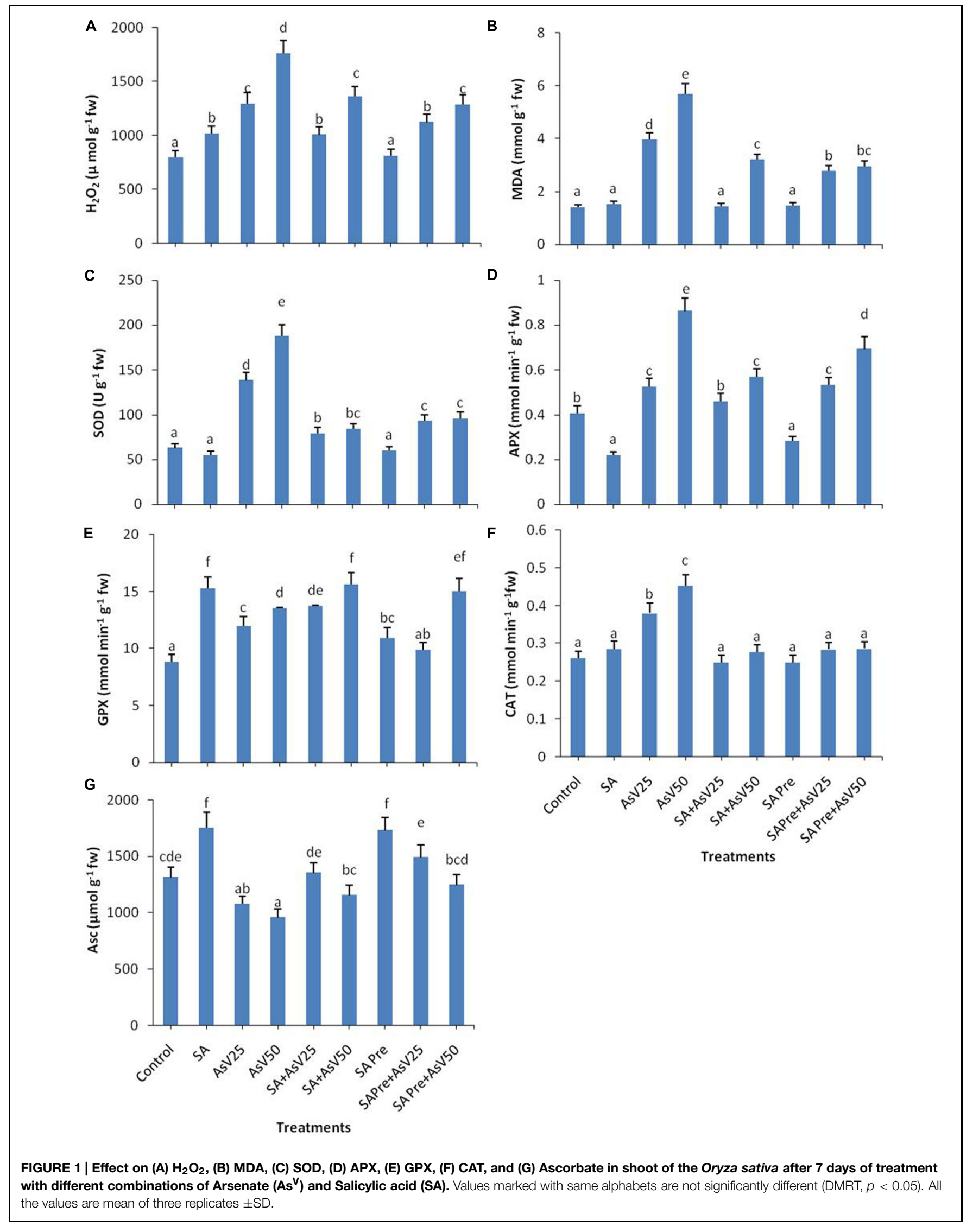


Salicylic acid alone treatment reduced the APX activity to approximately half while $50 \mu \mathrm{M} \mathrm{As}{ }^{\mathrm{V}}$ treatment approximately doubled the APX activity than control. Co-application of SA and As ${ }^{\mathrm{V}} 50$ reduced APX activity by $34 \%$ also SA pre-treatment (SA Pre $\left.+\mathrm{As}^{\mathrm{V}} 50\right)$ reduced APX activity by $20 \%$ than $\mathrm{As}^{\mathrm{V}} 50$ treated plants (Figure 1D). SA alone treatment enhanced the GPX activity by ca. twofold, furthermore $\mathrm{As}^{\mathrm{V}}$ treatment also enhanced the activity significantly than control. Co-application of SA and $\mathrm{As} \mathrm{V}$ also enhanced GPX activity than corresponding alone $\mathrm{As}^{\mathrm{V}}$ treated plants (Figure 1E). Under As ${ }^{\mathrm{V}}$ stress, CAT activity was enhanced 45 and $72 \%$ at 25 and $50 \mu \mathrm{M}$, respectively, than control. Coapplication or pre-treatment of $\mathrm{SA}$ and $\mathrm{As}^{\mathrm{V}}$, reduced the CAT activity than $\mathrm{As}^{\mathrm{V}}$ alone exposed plants (Figure 1F). SA alone treatment has enhanced the Asc content by $33 \%$ while exposure to $50 \mu \mathrm{As} \mathrm{V}^{\mathrm{V}}$ reduced the Asc level by upto $27 \%$ than control. Co-application of SA and $\mathrm{As}^{\mathrm{V}}$ further enhanced the Asc content significantly than corresponding $\mathrm{As}^{\mathrm{V}}$ alone treated plants. SA pre-treatment also enhanced the level of Asc upon $\mathrm{As}^{\mathrm{V}}$ exposure in all treatments than corresponding $\mathrm{As}^{\mathrm{V}}$ exposed plants (Figure 1G).

\section{Nitrate Reductase, Nitrite, and Endogenous Level of SA}

Nitrate reductase activity was significantly enhanced by SA as well as $\mathrm{As}^{\mathrm{V}}$ treated plants in comparison to control. Co-application of
SA with lower $\mathrm{As}^{\mathrm{V}}(25 \mu \mathrm{M})$ has enhanced the NR activity significantly while with higher $\mathrm{As}^{\mathrm{V}}(50 \mu \mathrm{M}) \mathrm{NR}$ activity was reduced significantly than As alone treatments. SA pre-treatment to As $\mathrm{V}$ exposed plants has no significant impact on NR activity than corresponding alone $\mathrm{As}^{\mathrm{V}}$ exposed plants (Figure 2A).

The level of nitrite was almost doubled in SA alone treated plants, while a dose dependent decrease in nitrite level was observed under $\mathrm{As}^{\mathrm{V}}$ stress plants than control. Co-application of SA and $\mathrm{As}^{\mathrm{V}}$ enhanced the nitrite level in comparison to $\mathrm{As} \mathrm{V}$ alone exposed plants. SA pre-treated plants had almost double nitrite than control. However, when SA pre-treated plants were exposed to $\mathrm{As}^{\mathrm{V}}$ the levels of nitrite was lower than control and were comparable to $\mathrm{As}^{\mathrm{V}}$ alone treated plants (Figure 2B). There was no significant change in level of endogenous level of SA in shoot in all treatments except for SA alone treated plants where endogenous level of SA was enhanced significantly than control (Figure 2C).

\section{Non-Protein Thiol Metabolism}

The level of total non-protein thiol (NPT) did not show any significant change in response to the treatments in comparison to control except for SA alone treated plant (Figure 3A). SA treatment has enhanced the GSH level by $25 \%$ while $\mathrm{As}^{\mathrm{V}}$ stress has reduced the GSH content in dose dependent manner than control. Co-application of SA and $\mathrm{As}^{\mathrm{V}}$ enhanced GSH content 7
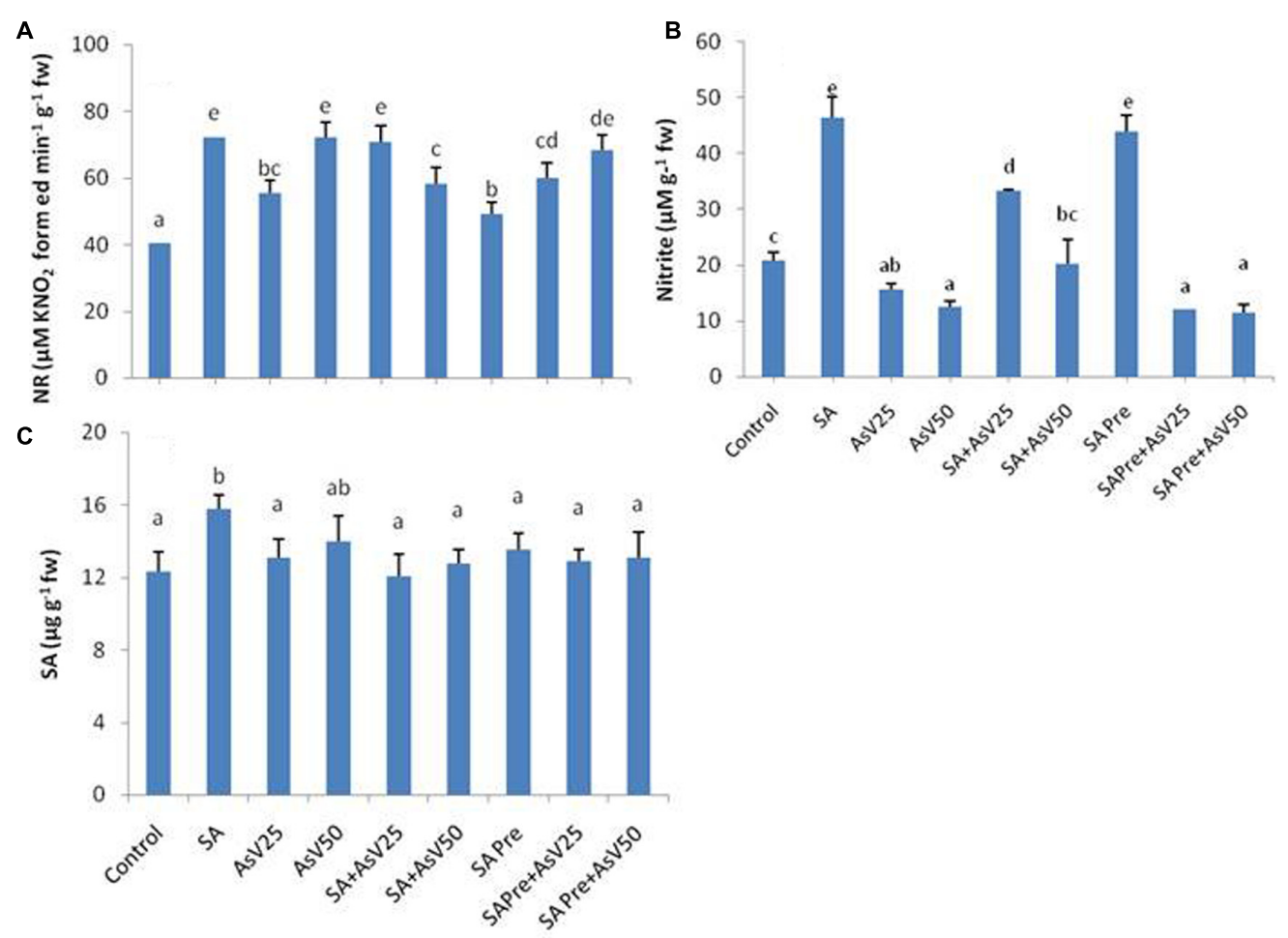

Treatments

FIGURE 2 | Effect on (A) Nitrate reductase, (B) Nitrite and (C) Endogenous level of SA in shoot of the Oryza sativa after 7 days of treatment with different combinations of $\mathbf{A s}^{\mathbf{v}}$ and $\mathbf{S A}$. Values marked with same alphabets are not significantly different (DMRT, $\left.p<0.05\right)$. All the values are means of three replicates $\pm S D$. 

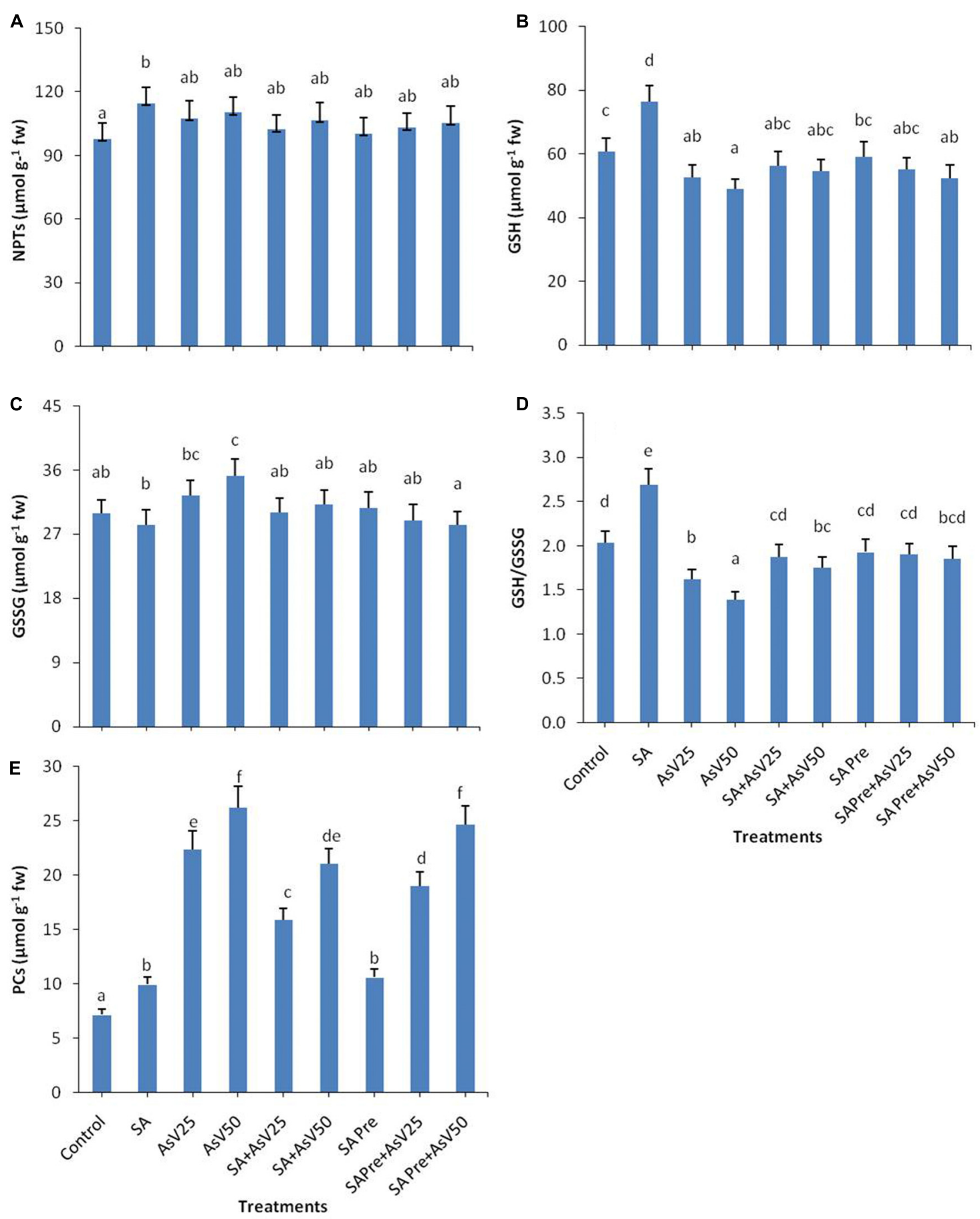

Treatments

FIGURE 3 | Effect on (A) NPTs, (B) GSH, (C) GSSG, (D) ratio of GSH/GSSG, and (E) Phytochelatins (PCs) in shoot of the Oryza sativa after 7 days of treatment with different combinations of $\mathbf{A s}^{\mathbf{V}}$ and $\mathbf{S A}$. Values marked with same alphabets are not significantly different (DMRT, $\left.p<0.05\right)$. All the values are means of three replicates \pm SD.

and $11 \%$ than corresponding $\mathrm{As}^{\mathrm{V}}$ alone treated plants though the levels were not statistically significant different than control. Pretreatment of SA with $\mathrm{As}^{\mathrm{V}}$ had no significant impact on GSH level than corresponding $\mathrm{As}^{\mathrm{V}}$ alone treated plants (Figure 3B). Alone SA treatment had no significant impact on GSSG level while
As ${ }^{\mathrm{V}} 50$ has significantly enhanced GSSG content than control (Figure 3C). Ratio of GSH/GSSG was enhanced by $32 \%$ in SA treatment plants while in $\mathrm{As}^{\mathrm{V}}$ treated plant the ratio was reduced by 20 and $31 \%$ in dose dependent manner than control. Coapplication of SA and $\mathrm{As}^{\mathrm{V}}$ has enhanced the GSH/GSSG ratio 
than their corresponding $\mathrm{As}^{\mathrm{V}}$ alone treated plants. SA pre-treated $\mathrm{As}^{\mathrm{V}}$ exposed plants also showed enhanced GSH/GSSG ratio than $\mathrm{As}^{\mathrm{V}}$ alone treated plants (Figure 3D).

Both SA alone and $\mathrm{As}^{V}$ alone treatments enhanced the level of PCs to 1.4 and up to 3.5 -fold (at $\mathrm{As}^{V} 50$ ), respectively, as compared to control. Co-application of SA and $\mathrm{As}^{V}$ reduced the PCs accumulation by 29 and $19 \%$ than corresponding alone $\mathrm{As}^{V}$ treated plants though the values were still significantly higher than controls. Similar effects were observed in SA pre-treated plants both with and without $\mathrm{As}^{V}$ (Figure 3E).

\section{Arsenite and Iron Transporters}

Salicylic acid alone treatment enhanced the expression level of OsLsi1 to ca. threefold than control. Arsenate alone treatment also enhanced OsLsil expression significantly in comparison to control though the levels were far lower than SA alone. Coapplication of SA and $\mathrm{As}^{\mathrm{V}}$ enhanced OsLsi1 expression around twofolds than $\mathrm{As}^{\mathrm{V}}$ alone treated roots. Pre-treatment of SA, with or without $\mathrm{As}^{\mathrm{V}}$, had no significant impact on OsLsilexpressionin comparison to control or respective $\mathrm{As}^{\mathrm{V}}$ alone treatments (Figure 4A).

Arsenate exposure enhanced the OsLsi2 expression level to ca. five- and sevenfold in dose dependent manner than control. Co-application of $\mathrm{SA}$ and $\mathrm{As}^{\mathrm{V}}$ as well SA pre-treatment to $\mathrm{As} \mathrm{V}$ exposed plants lowered the expression of OsLsi2 in comparison to $\mathrm{As}^{\mathrm{V}}$ alone treatments, however, the levels were still significantly higher than control roots (Figure 4B).

The expression of OsNRAMP5 was enhanced more about threefold in $\mathrm{As}^{\mathrm{V}}$ treated plant roots, however, $\mathrm{SA}$ alone treatment also increased the expression of OsNRAMP5 by about 2.5 -folds. Co-application of SA and $A s^{\mathrm{V}}$ has reduced the expression level by $20 \%$ and $31 \%$ in comparison to respective $A s \mathrm{~V}$ alone exposed plants. SA pre-treatment slightly reduced the expression level of OsNRAMP5 in comparison to $\mathrm{As}^{\mathrm{V}}$ alone treatment which was significant at $50 \mu \mathrm{M} \mathrm{As}{ }^{\mathrm{V}}$.

OsIRO2 expression level enhanced 13-fold in SA treated plants and $\mathrm{As}^{\mathrm{V}} 25$ and $A s^{\mathrm{V}} 50$ have enhanced ca. eight and ca. sixfold than control. Co-application of SA and $\mathrm{As}^{\mathrm{V}}$ further enhanced expression level and that was comparable to SA treated plants. $\mathrm{SA}$ pre-treatment to $\mathrm{As}^{\mathrm{V}} 50$ stressed plants significantly increased the expression level of $\mathrm{OsIRO} 2$ than $\mathrm{As}^{\mathrm{V}}$ 50alone treated plants.

OsFRDL1 expression level was decreased under $\mathrm{As}^{\mathrm{V}}$ stress in dose dependent manner than control. Co-application of $\mathrm{SA}$ and $\mathrm{As}^{\mathrm{V}}$ enhanced the expression level significantly than corresponding $\mathrm{As}^{\mathrm{V}}$ alone treated plants. In $\mathrm{SA}$ pretreated plants exposed to $\mathrm{As}^{\mathrm{V}} 50$ the expression level of OsFRDL1 approximately doubled than $\mathrm{As}^{\mathrm{V}} 50$ alone treated plants.

OsYSL2 expression level was enhanced to ca. 16-fold in SA alone treated plants and $\mathrm{As}^{\mathrm{V}}$ alone treatment enhanced the expression by about 10- and 13-fold in dose dependent manner than control. Co-application of $\mathrm{SA}$ and $\mathrm{As}^{\mathrm{V}}$ reduced the expression level than SA alone as well as corresponding $\mathrm{As}^{\mathrm{V}}$ alone treated plants. SA pre-treatment also enhanced the expression level 13-fold than control. SA pre-treatment to $\mathrm{As}^{\mathrm{V}}$ stressed plants sharply declined the expression level than corresponding alone $\mathrm{As}^{\mathrm{V}}$ treated plants (Figures $4 \mathrm{C}-\mathbf{F}$ ).

\section{Discussions}

Salicylic acid serves as an important signaling molecule in plant system which has been shown to play role in against heavy metal toxicity (as detailed in introduction). The present experiment was designed to investigate the ameliorative effect of SA during As toxicity. The co-application and pre-treatment of SA with As was used to investigate persistence of signaling aspects of SA.

Arsenic is well known to adversely affect the plant growth and development upon its accumulation (Kumar et al., 2015). In present study as well a significant amount of As was accumulated by the rice plant that hampered the plant growth severely. Application of SA, either co- or pre- treatment with $\mathrm{As}^{\mathrm{V}}$ has significantly reduced the total accumulation of As (Root + shoot) with more reduction in the shoot. Though, the co-application of SA was more effective in reducing As accumulation than pretreatment of SA. Thus, SA treatment has negatively impacted the root to shoot translocation of As. This might be due to SAmediated down regulation of root to shoot As transporters. In present study OsLsi2, transporter responsible for root to shoot $\mathrm{As}^{\mathrm{III}}$ transport in rice ( $\mathrm{Ma}$ et al., 2008), has been found to be down regulated at mRNA level. Since As ${ }^{\mathrm{III}}$ is the dominant form inside the plant (Pickering et al., 2000; Mishra et al., 2013) and also probably the main As species translocated to the shoots. Thus, down regulation of OsLsi2 would negatively affect the As accumulation. In the present study As accumulation was positively correlation with OsLsi2 expression level $(R=0.87)$. Down regulation of OsLsi2was resulted in lower As accumulation in rice shoots in response to thiourea supplementation with As (Srivastava et al., 2014). OsLsi1 is primarily responsible for As ${ }^{\text {III }}$ transport to root from extracellular medium, was not found correlated with root uptake of Asin present study. This might be due to fact that in present experiment plants were treated with $\mathrm{As}^{\mathrm{V}}$ which is transported by the phosphate transporters (Tripathi et al., 2007). Alternatively, SA has been reported to activate ATP-binding cassette $(\mathrm{ABC})$ transporters in soybean (Eichhorn et al., 2006). The ABC transporters are responsible for vacuolar sequestration of As(III)-PC complexes (Song et al., 2010). Therefore, it might be possible that most of the accumulated As in SA treated rice plants were sequestered in root vacuoles in the form of As(III)-PC, as a result less As could be transported to the shoot. Further, SA pre-treatment has been reported to enhance PCs synthesis in maize root (Szalai et al., 2013). Although SA mediated resistance against heavy metal viz., $\mathrm{Cd}$, and $\mathrm{Mn}$, has reported in previous studies (Metwally et al., 2003: Shi and Zhu, 2008) no reduction in the level of accumulation was observed. Since less accumulation of metalloid in shoot might also affect its level in grain which would have great implications with respect to human toxicity through food chain As contamination.

In present study SA treatment has enhanced the plant growth in terms of root, shoot length and biomass. Co-application of $\mathrm{SA}$ and $\mathrm{As}^{\mathrm{V}}$, partially restored the plant growth in $\mathrm{As}^{\mathrm{V}}$ exposed plants. Growth stimulating effects of SA has been previously reported in soybean (Gutiérrez-Coronado et al., 1998), wheat (Shakirova et al., 2003), and maize (Gunes et al., 


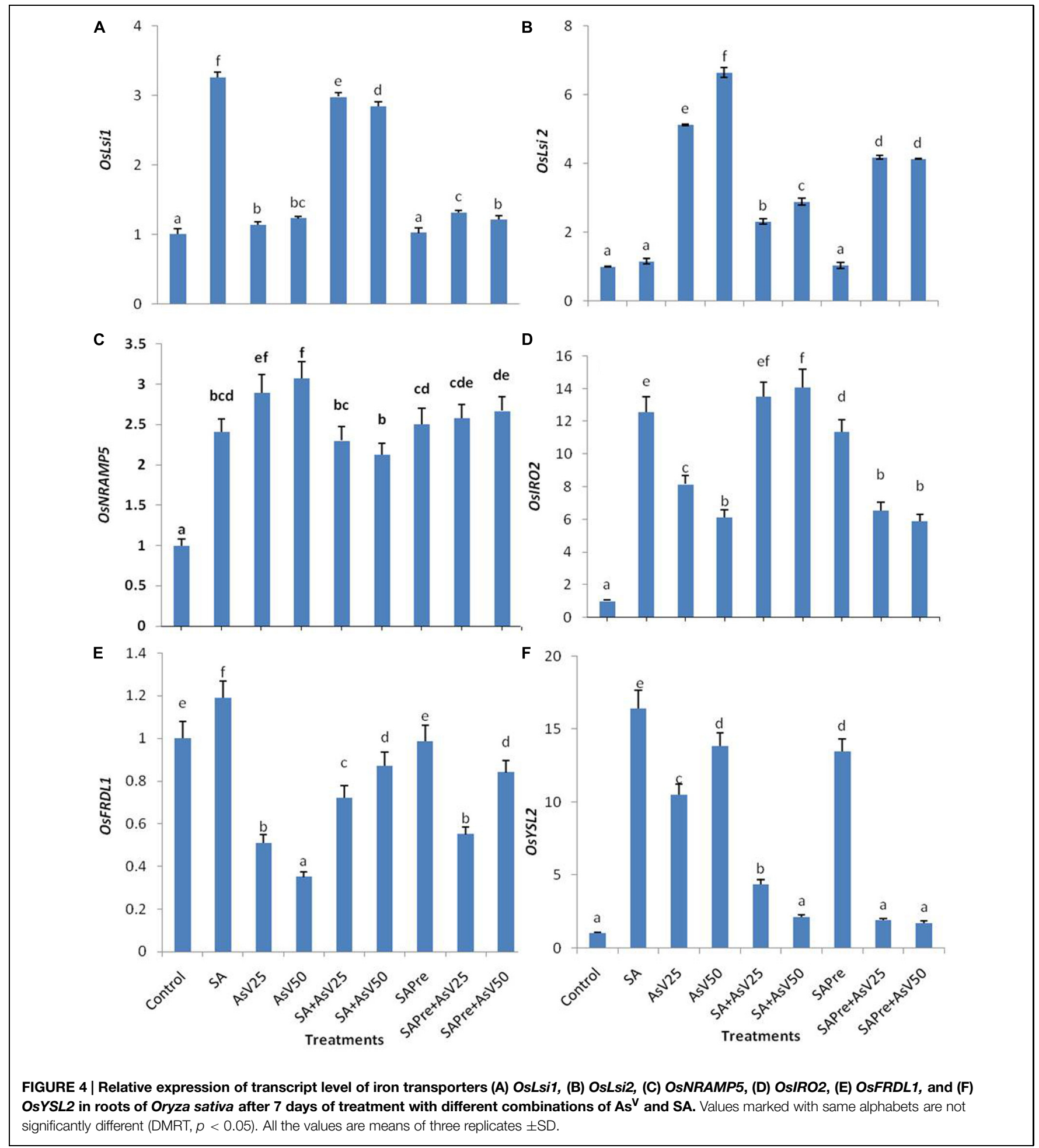

2007). This growth restoration by SA could be auxin mediated or due to lowering of As accumulation in shoot. In SA treated wheat seedlings, higher level of auxin has been reported (Shakirova et al., 2003). SA inducible transcription factors (OBP1, OBP2, and OBP3) were found to be responsive to auxin (Kang and Singh, 2000). Pre-treatment of SA also reverted the $A s^{\mathrm{V}}$ mediated inhibition of plant growth. In present study, a marked reduction in chlorophyll content was observed in $\mathrm{As}^{\mathrm{V}}$ treated plants. Similar results were previously reported by Rahman et al. (2007) in rice and by Mishra et al. (2014) in Ceratophyllum. SA supplementation to $\mathrm{As}^{\mathrm{V}}$ treated plants reverted $\mathrm{As}^{\mathrm{V}}$ induced chlorosis. Similar reversion of 
chlorosis was observed in maize under salinity stress (Khodary, 2004). In present study $\mathrm{As}^{\mathrm{V}}$ also reduced the Fe content in shoot that may also be responsible for $\mathrm{As}^{\mathrm{V}}$ mediated chlorosis while SA has enhanced the iron content in shoot and reverted the chlorosis. Previously Kong et al. (2014) also reported the increased uptake of $\mathrm{Fe}$ in Arachis hypogaea by foliar application of SA. SA induces the nitric oxide (NO) synthesis in plants (Zottini et al., 2007) that is reported to enhance the bioavailability of Fe (Graziano and Lamattina, 2007). In present study NR activity and nitrite level was also enhanced by SA treatment, indicating enhanced level of $\mathrm{NO}$ that also supports above mentioned hypothesis of SA mediated enhancement of NO leading to enhanced $\mathrm{Fe}$ availability and increase in photosynthetic pigments.

OsFRDL1, responsible for $\mathrm{Fe}$ efflux into xylem (Inoue et al., 2004), was down regulated in $\mathrm{As}^{\mathrm{V}}$ stressed plants and this decrease was concomitant with reduced Fe accumulation in shoot. OsYSL2, responsible for long distance transport of $\mathrm{Fe}$ (Ishimaru et al., 2010), was enhanced in both $\mathrm{SA}$, and $\mathrm{As}^{\mathrm{V}}$ treated plants, however, no increase in Fe accumulation in shoot was observed. OsNRAMP5 is involved in uptake of Fe in root (Ishimaru et al., 2012). The expression of OsNRAMP5 was enhanced in both SA and $\mathrm{As}^{\mathrm{V}}$ treated plants and an increase in Fe accumulation in root was observed as well.

Inside the cell As induces ROS synthesis that leads to oxidative stress (Finnegan and Chen, 2012). In present study oxidative stress is indicated by enhanced level of $\mathrm{H}_{2} \mathrm{O}_{2}$ and MDA content in $\mathrm{As}^{\mathrm{V}}$ treated plant as reported earlier in rice (Tripathi et al., 2012). Disturbed redox homeostasis in response to $\mathrm{As}^{\mathrm{V}}$ has been reported as the main factor for hampered growth of rice seedlings (Srivastava et al., 2014). SA treatment reduced the level of $\mathrm{As}^{\mathrm{V}}$ induced $\mathrm{H}_{2} \mathrm{O}_{2}$ and MDA which indicates that $\mathrm{SA}$ protected the plant against $\mathrm{As}^{\mathrm{V}}$ mediated oxidative stress. Similar protective effects of SA has been observed against Cd stress in rice (Guo et al., 2007) and barley (Metwally et al., 2003) and against As stress in Arabidopsis (Odjegba, 2012). SA mediated responses are associated with $\mathrm{H}_{2} \mathrm{O}_{2}$ accumulation (Drazic and Mihailovic, 2005). At moderate level, $\mathrm{H}_{2} \mathrm{O}_{2}$ serves as a secondary messenger for activation of stress resistance mechanism in plants (Noctor and Foyer, 1998). In present study SA application activated a slight accumulation of $\mathrm{H}_{2} \mathrm{O}_{2}$.

Ascorbate and glutathione (GSH/GSSG) are two important antioxidants. They are redox buffering agents in the apoplast and protect the plasma membrane from oxidation (Noctor and Foyer, 1998). The ratio of GSH/ GSSG is an important marker for oxidative stress (Tausz et al., 2004). The reduced GSH/ GSSG ratio in present study showed disturbed redox balance upon $\mathrm{As}^{\mathrm{V}}$ exposure. Application of SA has enhanced the GSH/ GSSG ratio. Enhanced GSH/ GSSG ratio in response to SA has also been reported in cucumber seedlings (Shi and Zhu, 2008). The enhanced $A s \mathrm{~V}$ tolerance upon thiourea application was suggested to be associated with TU ability to maintain plant redox homeostasis through improved GSH/GSSG ratio (Srivastava et al., 2014). Ascorbate is an effective scavenger for free radicals (Hasanuzzaman and Fujita, 2013). Co-application of
$\mathrm{SA}$ and $\mathrm{As}^{\mathrm{V}}$ also enhanced the level of Asc thus improving the redox balance under $\mathrm{As}^{\mathrm{V}}$ stress. Similar results were observed in Alfa during mercury stress (Zhou et al., 2009). The increase in the level of GSH might be due to the fact that gene encoding glutathione-dependent formaldehyde dehydrogenase /GSNO reductase was activated by $\mathrm{SA}$ in Arabidopsis (D $\imath$ ìaz et al., 2003).

In present study, under $\mathrm{As}^{\mathrm{V}}$ stress the activity of antioxidant enzymes APX, GPX, SOD, and CAT were enhanced in dose dependent manner. These enzymes consume the $\mathrm{H}_{2} \mathrm{O}_{2}$ as substrate so with the enhancement of $\mathrm{H}_{2} \mathrm{O}_{2}$ concentration, activity of these enzymes also enhanced. SA has high affinity to CAT and APX thereby inhibits their activities (Vlot et al., 2009; Manohar et al., 2015). In the present study SA supplementation to $\mathrm{As}^{\mathrm{V}}$ stressed plants reduced the APX and CAT activity than $\mathrm{As}^{\mathrm{V}}$ alone treated plants. SA is believed to inhibit CAT by the chelation of heme $\mathrm{Fe}$ and by causing conformational changes (Rüffer et al., 1995). However, Durner and Klessig (1996) suggested that SAmediated inhibition of CAT probably results from peroxidative reactions.

Guaiacol peroxidase exists in various isoenzyme forms in rice and has varied functions in plant metabolism but $\mathrm{H}_{2} \mathrm{O}_{2}$ serves as necessary substrate for their activity. Arsenate stress enhanced the GPX activity in dose dependent manner. SA enhanced the activity of GPX as previously reported in Medicago sativa (Zhou et al., 2009) and in rice (Guo et al., 2007).

In present study, no significant change was observed in endogenous level of SA under $A s^{\mathrm{V}}$ stress that is in contrast to previous studies which reported enhancement in endogenous level of SA under abiotic stress (Miura and Tada, 2014). Since rice shoot has high level of endogenous SA among all the plants tested for SA (Silverman et al., 1995), therefore, under abiotic stress endogenous level of SA may not show any significant change. Similar results were found under biotic stress when little or no change was observed in endogenous level of SA, during bacterial or fungal infection (Silverman et al., 1995; Yang et al., 2004).

\section{Conclusion}

Taken together it is evident from present work that SA has reduced the $\mathrm{As}^{\mathrm{V}}$ induced oxidative stress and effectively modulated the enzymatic and non-enzymatic antioxidants. SA also played a role in enhancing Asc, GSH, and PCs in plants subjected to $A s^{V}$ stress. SA reduced the As accumulation in shoot and also overcame the As induced Fe deficiency in shoot so the elaborated study of SA signaling may be helpful in developing the As resistant crops.

\section{Author Contributions}

RT, PT, VP, DC, Shekhar Mallick designed experiments and reviewed manuscript. AS, GD performed experimental work and prepared figures. MT Operated Thermocycler. Seema Mishra, SD 
reviewed manuscript. All authors have read and approved the manuscript.

\section{Acknowledgments}

The authors are thankful to Director, CSIR - National Botanical Research Institute (CSIR - NBRI), Lucknow for the facilities and for the financial support from the network projects (CSIR INDEPTH), New Delhi, India. AS is thankful to University Grant

\section{References}

Arnon, D. I. (1949). Copper enzymes in isolated chloroplasts. Polyphenoloxidase in Beta vulgaris. Plant Physiol. 24, 1-15. doi: 10.1104/pp.24.1.1

Beauchamp, C., and Fridovich, I. (1971). Superoxide dismutase: improved assays and an assay applicable to acrylamide gels. Anal. Biochem. 44, 276-287. doi: 10.1016/0003-2697(71)90370-8

Dì̀az, M., Achkor, H., Titarenko, E., and Martı̀nez, M. C. (2003). The gene encoding glutathione-dependent formaldehyde dehydrogenase/GSNO reductase is responsive to wounding, jasmonic acid and salicylic acid. FEBS Lett. 543, 136-139. doi: 10.1016/S0014-5793(03)00426-5

Drazic, G., and Mihailovic, N. (2005). Modification of cadmium toxicity in soybean seedlings by salicylic acid. Plant Sci. 168, 511-517. doi: 10.1016/j.plantsci.2004.09.019

Duan, G. L., Hu, Y., Liu, W. J., Kneer, R., Zhao, F. J., and Zhu, Y. G. (2011). Evidence for a role of phytochelatins in regulating arsenic accumulation in rice grain. Environ. Exp. Bot. 71, 416-421. doi: 10.1016/j.envexpbot.2011.02.016

Durner, J., and Klessig, D. F. (1996). Salicylic acid is a modulator of tobacco and mammalian catalases. J. Biol. Chem. 271, 28492-28501. doi: 10.1074/jbc.271.45.28492

Duxbury, A. C., and Yentsch, C. S. (1956). Plankton pigment nomographs. J. Mar. Res. 15, 92-101. doi: 10.1016/j.pestbp.2015.03.013ů2.01

Eichhorn, H., Klinghammer, M., Becht, P., and Tenhaken, R. (2006). Isolation of a novel ABC-transporter gene from soybean induced by salicylic acid. J. Exp. Bot. 57, 2193-2201. doi: 10.1093/jxb/erj179

Ellman, G. L. (1959). Tissue sulfhydryl groups. Arch. Biochem. Biophys. 82, 70-77. doi: 10.1016/0003-9861(59)90090-6

Finnegan, P. M., and Chen, W. (2012). Arsenic toxicity: the effects on plant metabolism. Front. Physiol. 3:182. doi: 10.3389/fphys.2012.00182

Graziano, M., and Lamattina, L. (2007). Nitric oxide accumulation is required for molecular and physiological responses to iron deficiency in tomato roots. Plant J. 52, 949-960. doi: 10.1111/j.1365-313X.2007.03283.x

Gunes, A., Inal, A., Alpaslan, M., Eraslan, F., Bagci, E. G., and Cicek, N. (2007). Salicylic acid induced changes on some physiological parameters symptomatic for oxidative stress and mineral nutrition in maize (Zea mays L.) grown under salinity. J. Plant Physiol. 164, 728-736. doi: 10.1016/j.jplph.2005.12.009

Guo, B., Liang, Y. C., Zhu, Y. G., and Zhao, F. J. (2007). Role of salicylic acid in alleviating oxidative damage in rice roots (Oryza sativa) subjected to cadmium stress. Environ. Pollut. 147, 743-749. doi: 10.1016/j.envpol.2006.09.007

Gutiérrez-Coronado, M. A., Trejo-López, C., and Larqué-Saavedra, A. (1998). Effects of salicylic acid on the growth of roots and shoots in soybean. Plant Physiol. Biochem. 36, 563-565. doi: 10.1016/S0981-9428(98)80003-X

Hageman, R. H., and Reed, A. J. (1980). Nitrate reductase from higher plants. Methods Enzymol. 69, 270-280. doi: 10.1016/S0076-6879(80)69026-0

Hasanuzzaman, M., and Fujita, M. (2013). Exogenous sodium nitroprusside alleviates arsenic-induced oxidative stress in wheat (Triticumaestivum L.) seedlings by enhancing antioxidant defense and glyoxalase system. Ecotoxicology 22, 584-596. doi: 10.1007/s10646-013-1050-4

Heath, R. L., and Packer, L. (1968). Photoperoxidation in isolated chloroplasts: I. Kinetics and stoichiometry of fatty acid peroxidation. Arch. Biochem. Biophys. 125, 189-198. doi: 10.1016/0003-9861(68)90654-1

Hissin, P. J., and Hilf, R. (1976). A fluorometric method for determination of oxidized and reduced glutathione in tissues. Anal. Biochem. 74, 214-226. doi: 10.1016/0003-2697(76)90326-2
Commission, New Delhi, India for the award of Junior/Senior Research Fellowship and Academy of Scientific and Innovative Research (AcSIR) for his Ph.D. registration.

\section{Supplementary Material}

The Supplementary Material for this article can be found online at: http://journal.frontiersin.org/article/10.3389/fpls. 2015.00340/abstract

Inoue, H., Suzuki, M., Takahashi, M., Nakanishi, H., Mori, S., and Nishizawa, N. K. (2004). A rice FRD'like (OsFRDL1) gene is expressed in the cells involved in long-distance transport. Soil Sci. Plant Nutr. 50, 1133-1140. doi: 10.1080/00380768.2004.10408586

Ishimaru, Y., Masuda, H., Bashir, K., Inoue, H., Tsukamoto, T., and Takahashi, M. (2010). Rice metal-nicotianamine transporter, OsYSL2, is required for the long-distance transport of iron and manganese. Plant J. 62, 379-390. doi: 10.1111/j.1365-313X.2010.04158.x

Ishimaru, Y., Suzuki, M., Tsukamoto, T., Suzuki, K., Nakazono, M., and Kobayashi, T. (2006). Rice plants take up iron as an $\mathrm{Fe}^{3+}$ phytosiderophore and as $\mathrm{Fe}^{2+}$. Plant J. 45, 335-346. doi: 10.1111/j.1365-313X.2005.02624.x

Ishimaru, Y., Takahashi, R., Bashir, K., Shimo, H., Senoura, T., and Sugimoto, K. (2012). Characterizing the role of rice NRAMP5 in manganese, iron and cadmium transport. Sci. Rep. 2, 286. doi: 10.1038/srep00286

Kang, H. G., and Singh, K. B. (2000). Characterization of salicylic acid-responsive, Arabidopsis Dof domain proteins: over expression of OBP3 leads to growth defects. Plant J. 21, 329-339. doi: 10.1046/j.1365-313x.2000.00678.x

Kato, M., and Shimizu, S. (1987). Chlorophyll metabolism in higher plants. VII. Chlorophyll degradation in senescing tobacco leaves; phenolic-dependent peroxidative degradation. Can. J. Bot. 65, 729-735. doi: 10.1139/b87-097

Khodary, S. E. A. (2004). Effect of salicylic acid on the growth, photosynthesis and carbohydrate metabolism in salt-stressed maize plants. Int. J. Agric. Biol. 6, 5-8.

Kobayashi, T., and Nishizawa, N. K. (2012). Iron uptake, translocation and regulation in higher plants. Annu. Rev. Plant Biol. 63, 131-152. doi: 10.1146/annurevarplant-042811-105522

Kong, J., Dong, Y., Xu, L., Liu, S., and Bai, X. (2014). Effects of foliar application of salicylic acid and nitric oxide in alleviating iron deficiency induced chlorosis of Arachis hypogaea L. Bot. Stud. 55, 9. doi: 10.1186/1999-3110-55-9

Kumar, A., Dwivedi, S., Singh, R. P., Chakrabarty, D., Mallick, S., and Trivedi, P. K. (2014a). Evaluation of amino acid profile in contrasting arsenic accumulating rice genotypes under arsenic stress. Biol. Plant. 58, 733-742. doi: 10.1007/s10535-014-0435-4

Kumar, A., Singh, R. P., Singh, P. K., Awasthi, S., Chakrabarty, D., and Trivedi, P. K. (2014b). Selenium ameliorates arsenic induced oxidative stress through modulation of antioxidant enzymes and thiols in rice (Oryza sativa L). Ecotoxicology 23, 1153-1163. doi: 10.1007/s10646-014-1257-z

Kumar, S., Dubey, R. S., Tripathi, R. D., Chakrabarty, D., and Trivedi, P. K. (2015). Omics and biotechnology of arsenic stress and detoxification in plants: current updates and prospective. Environ. Int. 74, 221-230. doi: 10.1016/j.envint.2014.10.019

Livak, K. J., and Schmittgen, T. D. (2001). Analysis of relative gene expression data using real-time quantitative PCR and the $2-\Delta \Delta C T$ Method. Methods 2, 402-408. doi: 10.1006/meth.2001.1262

Ma, J. F., Yamaji, N., Mitani, N., Xu, X. Y., Su, Y. H., McGrath, S. P., et al. (2008). Transporters of arsenite in rice and their role in arsenic accumulation in rice grain. Proc. Natl. Acad. Sci. U.S.A. 105, 9931-9935. doi: 10.1073/pnas.0802361105

Mallick, S., Kumar, N., Singh, A. P., Sinam, G., Yadav, R. N., and Sinha, S. (2012). Role of sulfate in detoxification of arsenate induced toxicity in Zea mays L. (SRHM 445) nutrient status and antioxidants. J. Plant Interact. 8, 140-154. doi: 10.1080/17429145.2012.734863

Manohar, M., Tian, M., Moreau, M., Park, S. W., Choi, H. W., and Fei, Z. (2015). Identification of multiple salicylic acid-binding proteins using two high throughput screens. Front. Plant Sci. 5:777. doi: 10.3389/fpls.2014.00777 
McCarty, K. M., Hanh, H. T., and Kim, K. W. (2011). Arsenic geochemistry and human health in South East Asia. Rev. Environ. Health 26, 71-78. doi: 10.1515/reveh.2011.010

Metwally, A., Finkemeier, I., Georgi, M., and Dietz, K. J. (2003). Salicylic acid alleviates the cadmium toxicity in barley seedlings. Plant Physiol.132, 272-281. doi: 10.1104/pp.102.018457

Mishra, S., Stärk, H. J., and Küpper, H. (2014). A different sequence of events than previously reported leads to arsenic-induced damage in Ceratophyllum demersum L. Metallomics 6, 444-454. doi: 10.1039/c3mt00317e

Mishra, S., Wellenreuther, G., Mattusch, J., Stärk, H. J., and Küpper, H. (2013). Speciation and distribution of arsenic in the nonhyperaccumulator macrophyte Ceratophyllum demersum. Plant Physiol. 163, 1396-1408. doi: 10.1104/pp.113.224303

Miura, K., and Tada, Y. (2014). Regulation of water, salinity, and cold stress responses by salicylic acid. Front. Plant Sci. 5:4. doi: 10.3389/fpls.2014.00004

Nakano, Y., and Asada, K. (1981). Hydrogen peroxide is scavenged by ascorbatespecific peroxidase in spinach chloroplasts. Plant Cell Physiol. 22, 867-880.

Noctor, G., and Foyer, C. H. (1998). Ascorbate and glutathione: keeping active oxygen under control. Annu. Rev. Plant Biol. 49, 249-279. doi: 10.1146/annurev.arplant.49.1.249

Noriega, G., Caggiano, E., Lecube, M. L., Santa Cruz, D., Batlle, A., Tomaro, M., et al. (2012). The role of salicylic acid in the prevention of oxidative stress elicited by cadmium in soybean plants. Biometals 25, 1155-1165. doi: $10.1007 / \mathrm{s} 10534-012-9577-\mathrm{z}$

Odjegba, V. J. (2012). Exogenous salicylic acid alleviates arsenic toxicity in Arabidopsis thaliana. Indian J. Inno. Dev. 1, 515-522.

Ogo, Y., Itai, R. N., Nakanishi, H., Kobayashi, T., Takahashi, M., and Mori, S. (2007). The rice bHLH protein OsIRO2 is an essential regulator of the genes involved in Fe uptake under Fe-deficient conditions. Plant J. 51, 366-377. doi: 10.1111/j.1365-313X.2007.03149.x

Pan, X., Welti, R., and Wang, X. (2010). Quantitative analysis of major plant hormones in crude plant extracts by high-performance liquid chromatographymass spectrometry. Nat. Protoc. 5, 986-992. doi: 10.1038/nprot.2010.37

Pickering, I. J., Prince, R. C., George, M. J., Smith, R. D., George, G. N., and Salt, D. E. (2000). Reduction and coordination of arsenic in Indian mustard. Plant Physiol. 122, 1171-1178. doi: 10.1104/pp.122.4.1171

Rahman, M. A., Hasegawa, H., Rahman, M. M., Islam, M. N., Miah, M. A., and Tasmen, A. (2007). Effect of arsenic on photosynthesis, growth and yield of five widely cultivated rice (Oryzasativa L.) varieties in Bangladesh. Chemosphere 67, 1072-1079. doi: 10.1016/j.chemosphere.2006.11.061

Römheld, V., and Marschner, H. (1986). Evidence for a specific uptake system for iron phytosiderophore in roots of grasses. Plant Physiol. 80, 175-180. doi: 10.1104/pp.80.1.175

Rüffer, M., Steipe, B., and Zenk, M. H. (1995). Evidence against specific binding of salicylic acid to plant catalase. FEBS Lett. 377, 175-180. doi: 10.1016/00145793(95)01334-2

Scandalios, J. G., Tsaftaris, A. S., Chandlee, J. M., and Skadsen, R. W. (1983). Expression of the developmentally regulated catalase (Cat) genes in maize. Dev. Genet. 4, 281-293. doi: 10.1002/dvg.1020040406

Shakirova, F., Sakhabudinova, A., Bezrukova, M. K., and Fathutdinova, M. D. (2003). Changes in the hormonal status of wheat seedlings induced by salicylic acid and salinity. Plant Sci. 164, 317-322. doi: 10.1016/S0168-9452(02)00415-6

Shi, Q., and Zhu, Z. (2008). Effects of exogenous salicylic acid on manganese toxicity, element contents and antioxidative system in cucumber. Environ. Exp. Bot. 63, 317-326. doi: 10.1016/j.envexpbot.2007.11.003

Shukla, V. K. S., Kokate, C. K., and Srivastava, K. C. (1979). Spectrophotometric determination of ascorbic acid. Microchem. J. 24, 124-126. doi: 10.1016/0026265X(79)90048-1

Silverman, P., Seskar, M., Kanter, D., Schweizer, P., Metraux, J. P., and Raskin, I. (1995). Salicylic acid in rice (biosynthesis, conjugation, and possible role). Plant Physiol. 108, 633-639.
Song, W. Y., Park, J., Mendoza-Cózatl, D. G., Suter-Grotemeyer, M., Shim, D., and Hörtensteiner, S. (2010). Arsenic tolerance in Arabidopsis is mediated by two ABCC-type phytochelatin transporters. Proc. Natl. Acad. Sci. U.S.A. 107, 21187-21192. doi: 10.1073/pnas.1013964107

Srivastava, A. K., Srivastava, S., Mishra, S., D’Souza, S. F., and Suprasanna, P. (2014). Identification of redox-regulated components of arsenate (As V) tolerance through thiourea supplementation in rice. Metallomics 6, 1718-1730. doi: 10.1039/C4MT00039K

Szalai, G., Krantev, A., Yordanova, R., Popova, L. P., and Janda, T. (2013). Influence of salicylic acid on phytochelatin synthesis in Zea mays during Cd stress. Turk. J. Bot. 37, 708-714

Takahashi, Y., Minamikawa, R., Hattori, K. H., Kurishima, K., Kihou, N., and Yuita, K. (2004). Arsenic behaviour in paddy fields during the cycle of flooded and non-flooded periods. Environ. Sci. Technol. 38, 1038-1044. doi: $10.1021 /$ es034383n

Tausz, M., Šircelj, H., and Grill, D. (2004). The glutathione system as a stress marker in plant ecophysiology: is a stress-response concept valid? J. Exp. Bot. 55, 1955-1962. doi: 10.1093/jxb/erh194

Tripathi, P., Mishra, A., Dwivedi, S., Chakrabarty, D., Trivedi, P. K., and Singh, R. P. (2012). Differential response of oxidative stress and thiol metabolism in contrasting rice genotypes for arsenic tolerance. Ecotoxicol. Environ. Saf. 79, 189-198. doi: 10.1016/j.ecoenv.2011.12.019

Tripathi, R. D., Srivastava, S., Mishra, S., Singh, N., Tuli, R., and Gupta, D. K. (2007). Arsenic hazards: strategies for tolerance and remediation by plants. Trends Biotechnol. 25, 158-165. doi: 10.1016/j.tibtech.2007.02.003

Velikova, V., Yordanov, I., and Edreva, A. (2000). Oxidative stress and some antioxidant systems in acid rain-treated bean plants: protective role of exogenous polyamines. Plant Sci. 151, 59-66. doi: 10.1016/S0168-9452(99)00197-1

Vlot, A. C., Dempsey, D. M. A., and Klessing, D. (2009). Salicylic acid, a multifaceted hormone to combat disease. Annu. Rev. Phytopathol. 47, 177-206. doi: 10.1146/annurev.phyto.050908.135202

Yang, Y., Qi, M., and Mei, C. (2004). Endogenous salicylic acid protects rice plants from oxidative damage caused by aging as well as biotic and abiotic stress. Plant J. 40, 909-919. doi: 10.1111/j.1365-313X.2004.02267.x

Yokosho, K., Yamaji, N., Ueno, D., Mitani, N., and Ma, J. F. (2009). OsFRDL1 is a citrate transporter required for efficient translocation of iron in rice. Plant Physiol. 149, 297-305. doi: 10.1104/pp.108.128132

Yuan, S., and Lin, S. S. (2008). Role of salicylic acid in plant abiotic stress. Z. Naturforsch. C 63, 313-320. doi: 10.1515/znc-2008-5-601

Yusuf, M., Fariduddin, Q., Varshney, P., and Ahmad, A. (2012). Salicylic acid minimizes nickel and/or salinity-induced toxicity in Indian mustard (Brassica juncea) through an improved antioxidant system. Environ. Sci. Pollut. Res. Int. 19, 8-18. doi: 10.1007/s11356-011-0531-3

Zhou, Z. S., Guo, K., Elbaz, A. A., and Yang, Z. M. (2009). Salicylic acid alleviates mercury toxicity by preventing oxidative stress in roots of Medicago sativa. Environ. Exp. Bot. 65, 27-34. doi: 10.1016/j.envexpbot.2008.06.001

Zottini, M., Costa, A., De Michele, R., Ruzzene, M., Carimi, F., and Schiavo, F. L. (2007). Salicylic acid activates nitric oxide synthesis in Arabidopsis. J. Exp. Bot. 58, 1397-1405. doi: 10.1093/jxb/erm001

Conflict of Interest Statement: The authors declare that the research was conducted in the absence of any commercial or financial relationships that could be construed as a potential conflict of interest.

Copyright (C) 2015 Singh, Dixit, Mishra, Dwivedi, Tiwari, Mallick, Pandey, Trivedi, Chakrabarty and Tripathi. This is an open-access article distributed under the terms of the Creative Commons Attribution License (CC BY). The use, distribution or reproduction in other forums is permitted, provided the original author(s) or licensor are credited and that the original publication in this journal is cited, in accordance with accepted academic practice. No use, distribution or reproduction is permitted which does not comply with these terms. 